\title{
TOURIST SATISFACTION AS A DRIVER OF DESTINATION MARKETING IMPROVEMENTS: THE CASE OF THE OPATIJA RIVIERA
}

\section{ZADOVOLJSTVO TURISTA KAO POKRETAČ UNAPRJEĐENJA MARKETINŠKIH AKTIVNOSTI DESTINACIJE: PRIMJER OPATIJSKE RIVIJERE}

\begin{abstract}
Lorena Bašan ${ }^{\text {a }}$, Jelena Kapešb ${ }^{\text {, Ana Kamenečkic }}$
a Faculty of Tourism and Hospitality Management, Primorska 42, P.P. 97, 51410 Opatija, CROATIA, e-mail: lorenab@fthm.hr

${ }^{b}$ Faculty of Tourism and Hospitality Management, Primorska 42, P.P. 97, 51410 Opatija, CROATIA, e-mail: jelena.kapes@fthm.hr c Faculty of Tourism and Hospitality Management, Primorska 42, P.P. 97, 51410 Opatija, CROATIA, e-mail: ana_kamenecki@ yahoo.com
\end{abstract}

\begin{abstract}
Purpose - This paper aims to identify critical destination attributes and examine their contribution to the overall satisfaction in relation to different age groups.

Design/Methodology/Approach - The research was conducted on the Opatija Riviera in Croatia using the survey method. Importance-performance analysis was used to identify priority attributes within the context of destination choice, and the results were compared with the quality provided from the destination management perspective. Pearson's correlation coefficient was calculated within three age groups to determine the statistical relationship between perceived quality of destination attributes and overall satisfaction with the destination.
\end{abstract}

Findings and implications - The results show negative and significant differences between the importance and the perceived quality of all destination attributes. The

\section{Sažetak}

Svrha - Svrha je rada identificirati ključne atribute turističke destinacije te istražiti njihov doprinos ukupnom zadovoljstvu s obzirom na različite dobne skupine turista.

Metodološki pristup - Istraživanje je provedeno anketiranjem na Opatijskoj rivijeri u Republici Hrvatskoj. Da bi se utvrdili prioritetni atributi u okviru izbora turističke destinacije, korištena je analiza važnosti i performansi. Dobiveni rezultati uspoređeni su s rezultatima ocjena pružene kvalitete atributa destinacije od strane menadžmenta turističke destinacije. Kako bi se istražila statistička povezanost između percipirane kvalitete atributa destinacije i ukupnog zadovoljstva s njome, izračunat je Pearsonov koeficijent korelacije za tri dobne skupine.

Rezultati i implikacije - Rezultati pokazuju negativne i statistički značajne razlike između važnosti i percipirane kvalitete svih promatranih atributa. Najveći je jaz 
largest gap refers to the traffic and facilities in the destination, which represent its main weaknesses and the highest priority. Concerning the relationships between the attributes' perceived quality and overall satisfaction with the destination, the highest correlation is found with regard to destination management attributes within all analyzed age groups. Differences relating to other attributes are evident among age groups. Furthermore, the analysis did not reveal significant differences between the perceived and the provided quality of destination attributes.

Limitations - The research has certain limitations. The first of them is related to the case-based character of this particular study. Thus, the specific findings cannot be generalized to the context of other destinations. In addition, there are drawbacks relating to the sample and the applied importance-performance analysis (IPA). The demographic structure of the respondents is uneven, since most respondents are female and younger in age, with only $9.5 \%$ of them aged from 55 to 74 . That IPA has critics among researchers is well known. In explaining implications for destination managers based on results from the implemented IPA, the results should be used as drivers for choosing tourist destinations, but not necessarily for creating a tourist experience.

Originality - This research study contributes to the scientific literature by providing evidence on the contribution of destination attributes to the overall destination satisfaction and differences attributable to the age of tourists. This approach could greatly help destination managers to develop suitable marketing strategies for target market segments.

Keywords - tourist destination attributes, tourist satisfaction, Opatija Riviera prisutan kod prometa i sadržaja u destinaciji predstavljajući time njezine glavne slabosti, ali i najveće prioritete. Promatrajući povezanost percipirane kvalitete atributa destinacije i ukupnog zadovoljstva destinacijom, najsnažnija je korelacija prisutna kod atributa vezanih uz destinacijski menadžment, a uočene su i razlike između pojedinih dobnih skupina vezano za ostale atribute. Nadalje, analiza nije pokazala statistički značajnu razliku između percipirane i pružene kvalitete atributa destinacije.

Ograničenja - Ovo istraživanje ima određena ograničenja. Prvo se odnosi na usmjerenost istraživanja na jednu destinaciju pa se rezultati ne mogu generalizirati u okviru ostalih destinacija. Ograničenja se odnose i na uzorak i IPA analizu. Prisutna je neujednačenost demografske strukture uzorka jer su ispitanici većinom žene i mlađe osobe, $\mathrm{s}$ udjelom od svega 9,5\% ispitanika u dobi od 55 do 74 godine. Kritike IPA analize dobro su poznate. Tumačenje implikacija za destinacijske menadžere temeljenih na rezultatima dobivenim primjenom IPA analize, treba promatrat i kao smjernice za izbor destinacije sa-mih turista, ali svakako ne i za kreiranje doživljaja turista u destinaciji.

Doprinos - Istraživanje doprinosi i znanstvenoj literaturi pružajući dokaze o povezanosti performansi atributa turističke destinacije i ukupnog zadovoljstva destinacijom te razlike $s$ obzirom na dob turista. Ovakav pristup može značajno pomoći destinacijskim menadžerima u razvoju odgovarajućih marketinških strategija za pojedina ciljna tržišta.

Ključne riječi - atributi turističke destinacije, zadovoljstvo turista, Opatijska rivijera 


\section{INTRODUCTION}

In today's increasingly competitive and saturated tourism market, gaining a competitive advantage has become a basis for destination success (Dwyer, Dragičević, Armenski, Mihalič \& Knežević Cvelbar, 2016). A review of the literature reveals that, besides economic features and sustainability, attractiveness and satisfaction are the key dimensions of destination competitiveness (Abreu-Novais, Ruhanen, \& Arcodia, 2015). To strengthen its competitive edge and achieve satisfaction, a destination should meet tourists' needs better than its competitors by developing and maintaining high-quality tourism products (Croes, 2011; Pansiri, 2014) because a destination's success and competitiveness depend heavily on the satisfaction level of its visitors (Soldić Frleta, 2018).

In recent years, tourists have become more discerning; in order to address constant changes and employ successful marketing strategies, it is essential to have detailed knowledge of the changes in tourists' desires and needs (Singh \& Tiwari, 2016). Understanding what tourists expect from a destination and how they perceive their destination experience can provide important guidance for destination managers (Griffin \& Edwards, 2012). The more detailed the knowledge about tourists' attitudes, the better destination managers can tailor the destination's offering to achieve visitor satisfaction (Soldić Frleta, 2018). Therefore, studying tourist attitudes in terms of competitive characteristics has become a key to understanding the manner in which tourists' needs can be met (Queiroz Neto, Dimmock, Lohmann \& Scott, 2019).

However, one of the most common issues regarding tourist satisfaction being cited in the literature is the fact that it is influenced by many factors. To facilitate measurement, the performance of a destination is often observed as a perception of various travel attributes (Ragavan, Subramonian \& Sharif, 2014). However, tourist satisfaction with certain attributes may differ depending on their demographic characteristics. According to Ragavan et al. (2014, p. 405), "demographic groups of tourists can be segregated based on the relationship of their perception of travel attributes with satisfaction."

Therefore, this paper aims to fill three main gaps identified in the literature: (1) identify critical destination attributes, (2) determine their correlation with overall satisfaction across different age groups, and (3) examine the gap between the perceived and the provided quality of attributes. In this study, importance-performance analysis (IPA) has been applied to combine the importance of destination attributes and their perceived performance. The study was conducted on the Opatija Riviera, a Croatian destination with one of the longest tourism traditions, which is a key factor in the tourism development of the Primorje-Gorski Kotar County to which it belongs.

Although destinations differ widely in terms of resources and tourism offerings, achieving tourist satisfaction by improving destination attributes is a common goal for all destination management organizations (DMO). In that respect, this study makes a contribution to both practice and theory. The research results could provide destination managers with valuable information regarding the reallocation of resources aimed at achieving visitor satisfaction. Furthermore, it could help destination marketers in tailoring a tourism offering that meets the needs of certain age groups. On the other hand, the paper expands the tourism literature by determining the relationship between satisfaction with destination attributes and tourist age groups.

The paper is organized in five main parts. After the introduction, a conceptual framework with an overview of previous research is provided. The third part details the methodology and is followed by research results and their discussion. The final, fifth part is the conclusion.

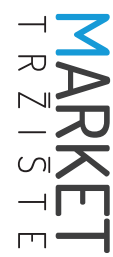




\section{CONCEPTUAL FRAMEWORK}

\subsection{Tourist satisfaction and destination marketing activities}

The concept of tourist satisfaction is well documented in the travel and tourism literature, as it is widely recognized that understanding tourist satisfaction is crucial for marketing professionals to improve destination performance (Aziz, Ariffin, Omar \& Siow, 2011; Dmitrović et al., 2009; Gnanapala, 2015; Meng, Tepanon \& Uysal, 2008). Extensive research over the last several decades has confirmed numerous positive outcomes. Indeed, tourist satisfaction creates positive word of mouth (Kozak \& Rimmington, 2000; Prebensen, Skallerud \& Chen, 2010; Wang, Tran \& Tran, 2017), it can serve as a predictor of tourist behaviour (Bagri \& Kala, 2015), and influences revisit intention (Alegre \& Caldera, 2009; Alegre \& Garau, 2010; Baker \& Crompton, 2000; Kozak \& Rimmington, 2000) and loyalty (Baker \& Crompton, 2000; Chi \& Qu, 2008; Eusebio \& Vieira, 2011; Rahim, Ignatius \& Adeoti, 2012; Rajesh, 2013; Yoon \& Uysal, 2005). Therefore, satisfaction is often seen as a source of competitive advantage (Bagri \& Kala, 2015; De Nisco, Riviezzo \& Napolitano, 2015; Meng et al., 2008) and it has become a key element of business strategy (Kotler, Bowen \& Makens, 2010).

As observed, tourist satisfaction is a prominent research topic among academics and practitioners, giving rise to different approaches to explaining this concept. In the marketing literature, satisfaction has often been defined as the overall post-purchase evaluation of customers compared to their pre-purchase expectations (Gnanapala, 2015; Kim, Suh \& Hwang, 2003; Kotler, 1999; Kozak, 2003; Oliver, 1997). With regard to this perspective, the connection to the expectancy-disconfirmation theory can be seen as the dominant framework for the evaluation of tourist satisfaction (Del Bosque \& Martin, 2008; Yüskel \& Yüskel, 2001). According to this paradigm proposed by Oliver (1980), tourist ex- pectations function as standards against which the destination is evaluated. When there is a gap between expectations and outcome, a disconfirmation occurs, which can manifest itself as satisfaction or dissatisfaction (Do Valle, Silva, Mendes \& Guerreiro, 2006; Eusebio \& Vieira, 2011; Yüskel \& Yüskel, 2001).

Some authors stress that tourist satisfaction is a feeling generated by the cognitive and emotional elements of the destination experience (Del Bosque \& Martin, 2008; Oliver, 1993; Wang, Zhang, Gu \& Zhen, 2009). Thus, satisfaction can be seen as an accumulated evaluation of various components and characteristics of the destination (Wang et al., 2009). It should be observed multidimensionally by evaluating several variables (Yoon \& Uysal, 2005).

A distinction between overall satisfaction and satisfaction with certain destination attributes should be made, as the evaluation may lead to the conclusion that tourists are sometimes not satisfied with the destination, but they are satisfied with certain attributes and vice versa (De Nisco et al., 2015). Accordingly, several models have emerged in which overall satisfaction is seen as a determinant of satisfaction with destination attributes (Alegre \& Cladera, 2006; Baker \& Crompton, 2000; Chi \& Qu, 2008; Oliver, 1993); according to various scholars, attribute satisfaction significantly influences overall satisfaction (Chi \& Qu, 2008; Devesa, Laguna \& Palacios, 2010; Oliver, 1993; Yoon \& Uysal, 2005).

Although researchers agree that management should focus on the evaluation of destination attributes (Alegre \& Cladera, 2006; De Nisco et al., 2015; Della Corte, Sciarelli, Cascella \& Del Gaudio, 2015; Do Valle et al., 2006; Gnanapala, 2015; Pawaskars \& Goel, 2017), there is ongoing debate about which attributes should be measured to obtain a holistic perspective on tourist satisfaction with a destination (Dwyer et al., 2016; Rašovska, Kubickova \& Ryglova, 2021).

To fill this gap, various studies on satisfaction with destination attributes have been conducted for different types of destinations. Several key attri- 
butes can be distinguished, such as the environment, accommodation, gastronomy, facilities, and attractions, depending on the destination type (Albayrak, Caber, Gonzales-Rodriguez \& Aksu, 2018; Alegre \& Cladera, 2006; Chi \& Qu, 2008; Djeri, Stamenković, Blešić, Miličević \& Ivkov, 2018; Kozak \& Rimmington, 2000; Meng et al., 2008; Pizam, Neumann \& Reichel, 1978; Rajesh, 2013; Ragavan et al., 2014). In addition, transportation and infrastructure (Guzman-Parra, Vila-Oblitas, \& Maqueda-Lafuente, 2016; Kozak, 2003; Shahrivar, 2012; Singh \& Tanwar, 2018), destination management activities (Kozak \& Rimmington, 2000; Pizam et al., 1978; Singh \& Tanwar, 2018), and the behavior of local residents (Guzman-Parra et al., 2016; Ragavan et al., 2014; Rašovska et al., 2021; Shahrivar, 2012) also appear as frequent subjects of research. Due to the individuality of each destination, the attributes and their importance also vary depending on destination type and visitor characteristics. Nevertheless, some common features can be identified and, irrespective of the destination type, a DMO has to maximize visitor satisfaction to achieve competitiveness.

\subsection{Importance-Performance Analysis (IPA)}

Tourist satisfaction requires thorough and continuous measurement; however, its evaluation still represents a challenge for researchers due to its complexity. In recent decades, multiple approaches and measurement techniques have emerged (Cronin \& Taylor, 1992; Oliver, 1980; Parasurman, Zethaml \& Berry, 1985; Philip \& Hazlett, 1997; Pizam \& Milman, 1993; Tribe \& Snaith, 1998). Observing existing studies, it is clear that satisfaction has been widely accepted as a function of the importance of certain attributes and an assessment of their performance (Guadagnolo, 1985; Meng et al., 2008). Therefore, this study focuses on the importance-performance analysis (IPA) as a successful tool that simultaneously measures the performance and the importance of target attributes.

Although, when observed independently, both importance and performance yield valuable in- formation for marketing managers, the results can sometimes be misleading. As Bagri and Kala (2015) state, for example, the study of perceived performance alone would indicate that characteristics with lower performance rates require management intervention. However, if performance rates are observed in line with importance scores, the results may show that importance is rated even lower than performance, indicating an acceptable level of satisfaction. Therefore, the full potential of these two dimensions can be realized only when they are combined (Levenburg \& Magal, 2004; Martilla \& James, 1977).

The IPA, developed by Martilla and James (1977), has been widely accepted by researchers within and outside of the tourism context thanks to its simplicity. It has been commonly used in various areas of tourism, such as hospitality (Beldona \& Cobangolu, 2007; Chen \& Chen, 2014; Chu \& Choi, 2000; Kim, Lee \& Han, 2019; Manhas \& Ramjit, 2011; Mikulić \& Prebežac, 2011), tourism destination marketing (Bagri \& Kala, 2015; Djeri et al., 2018; Disastra, Hanifa \& Sastika, 2018; Dwyer et al., 2016; Rašovska et al., 2021; Singh \& Tanwar, 2018), and tourism sustainability (Boley, McGehee \& Hammett, 2017; Cvelbar \& Dwyer, 2013; Sörensson \& Von Friedrichs, 2013). The basic notion of the IPA relates to the possibility of visually identifying gaps between tourists' perceptions of the importance and performance of a specific attribute (Boley et al., 2017).

As mentioned above, the identification of destination attributes plays an important role since they represent a measurement object, and poor performance of any of the destination attributes can lead to dissatisfaction with the destination (Pizam et al., 1978). In order to understand what to evaluate and to generate key attributes, a thorough literature review is needed (Duke \& Mount, 1996; Martilla \& James, 1977).

The result of the IPA is a two-dimensional grid divided into four quadrants. Each one proposes a particular managerial strategy based on the level of importance and performance of attributes. Quadrant 1 - concentrate here represents 


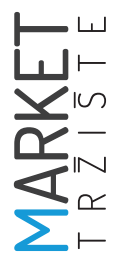

high importance and low performance, making these attributes the greatest weaknesses and the highest priority for destination managers. Quadrant 2 - keep up the good work represents high importance and high performance, indicating that the destination should maintain the quality of these attributes. Furthermore, quadrant 3 - lower priority means low importance and low performance of certain attributes that, consequently, do not require additional effort. Quadrant 4 - possible overkill represents low importance and high performance, suggesting a possible redistribution of funds to other, more prosperous attributes.

Despite its wide application, the IPA has faced some criticism. It has been commonly criticized because of its arbitrary importance measurement, as well as validity and reliability issues (Azzopardi \& Nash, 2013). The importance measurement is a common topic of debate since it can be measured directly as "stated importance" or indirectly as "derived importance", with the type of importance measurement greatly impacting the results (Mikulić, Krešić, Prebežac, Miličević \& Šerić, 2016). Furthermore, Mikulić and others (2016) warn about its common misuse. They state that strengths in the IPA matrix are commonly interpreted as competitive advantage; however, the IPA does not provide any insight into the performance of competitors. To deal with the identified issues, some alternatives have been proposed. For instance, Mikulić and others (2016) suggest applying Relative-Determinance Analysis (RDA) that combines stated and relative importance, and Competitive-Importance Analysis (CPA) that includes the competitive environment. Furthermore, Tontini, Picolo and Silveira (2014) have proposed the improvement-gap analysis (IGA), which measures the impact of the attributes on customer satisfaction, while Deng (2007) developed a revised IPA using a three-factor theory concept.

Regardless of the aforementioned issues and revised forms, when used properly, the IPA remains a highly valued tool used by many researchers. Specifically, an importance-performance map provides destination managers with valuable information on prioritization and allocation of limited resources from low- to high-impact areas (Griffin \& Edwards, 2012; Levenburg \& Magal, 2004; Singh \& Tanwar 2018). It represents an important management tool for the development of marketing strategies (Martilla \& James, 1977) and provides guidance for further activities to maintain destination competitiveness.

\subsection{Hypotheses development}

Numerous studies have addressed the antecedents and consequences of tourist satisfaction; however, the uniqueness of each destination and the complexity of tourist attitudes have led to a lack of consensus on destination attributes that generate satisfaction (De Nisco et al., 2015; Della Corte et al., 2015). As mentioned above, the identification of destination attributes plays an important role since they represent a measurement object, and poor performance of any of the destination attributes can lead to dissatisfaction with the destination (Pizam et al., 1978). To understand what to evaluate and how to generate key attributes, a thorough literature review is required (Duke \& Mount, 1996; Martilla \& James, 1977). This is particularly relevant for mature destinations that are trying to prevent the stagnation phase (Bernini \& Cagnone, 2012). Given that tourist satisfaction may vary depending on the destination life-cycle, and that Opatija is a mature seaside destination facing a seasonality issue (Vodeb \& Nemec Rudež, 2017), the first research hypothesis is formulated as follows:

H1: There is a significant difference between the importance and the perceived quality of destination attributes on the Opatija Riviera.

It should be noted that previous studies have shown that models in which destination attributes are correlated to the overall satisfaction with a destination provide more valuable management implications than models that only measure destination attributes individually (Fuchs \& Weiermair, 2003). Numerous studies in tourism literature indicate that 'the overall satisfaction of tourists is determined by how they evaluate des- 
tination attributes (Alegre \& Garau 2010; Baker \& Crompton, 2000; Yoon \& Uysal, 2005). Since there is a lack of knowledge about the relationship between destination attributes and overall satisfaction (Kwanisai \& Vengesayi, 2016), this study correlates these constructs. Thus, besides insight into which destination characteristics are more or less successful, it provides information about how these particular characteristics contribute to overall satisfaction with the destination. Following previous findings, the second hypothesis is proposed as follows:

H2: Overall satisfaction with a destination is significantly and positively correlated with satisfaction with the destination's attributes.

When it comes to tourist behaviour, demographic characteristics play a considerable role (Ragavan et al., 2014). Homburg and Giering (2001) warn, however, that research in many areas is abandoning the demographic criteria due to increased focus on the psychological aspect. Nonetheless, they suggest that incorporating demographic characteristics helps to increase the research relevance because these characteristica are easy to measure and handle by marketing practitioners. Therefore, researching age segments is crucial for the development of destination strategies (Li, Ali \& Kim, 2017). Although some researchers (Perović, Stanovčić, Morić \& Peković, 2012) found no significant differences in tourist satisfaction between different age groups, perhaps due to different approaches, several studies confirm that certain demographic variables, such as age, influence tourist satisfaction (Ghanbri, Naghizadeh \& Omrani, 2019; Ragavan et al., 2014; Shahrivar, 2012), attitudes, and even behavior (Li et al., 2017). When examining destination attributes, Singh and Tiwari (2016) found statistically significant differences between age groups regarding satisfaction with natural attributes, infrastructure, and services on site. Based on this, the third hypothesis was defined:

H3: There are significant differences in the correlation of overall satisfaction with destination attributes between different age groups.
The literature shows that the focus is often on the target destination's resources rather than on management activities, but both should be considered (Dwyer et al., 2016). As noted by Porter (2008), competitiveness is based both on available resources (comparative advantage) and on the ability of the destination to manage those resources (competitive advantage). Consequently, improving customer satisfaction is seen as one of the main functions of DMOs (Dmitrović et al., 2009; Pritchard \& Morgan, 1998). Thus, when evaluating tourism services, it is essential not only to assess them from the management perspective but also determine whether the tourist perception of quality is consistent with the quality provided (Ciunova-Shuleska, Palamidovska \& Grishin, 2013). In a study conducted in Opatija, Vodeb and Nemec Rudež (2017) identified gaps between the market supply-side and demand-side perception of destination attributes which called for further research. Based on this, the fourth hypothesis was formulated as follows:

H4: There is a significant difference between the perceived and the provided quality of destination attributes.

\section{METHODOLOGY}

According to the proposed research objectives and hypotheses, primary research was conducted based on two separate and interrelated surveys.

The first survey aimed to identify priority attributes within the context of destination choice. Therefore, the IPA was chosen as the method after considering all its previously mentioned benefits and limitations. According to Hudson and Shephard (1998, as cited in De Nisco et al., 2015), "for tourist destinations with rather little market research experience, Importance-Performance Analysis in its purest form can be used as a very powerful tool in marketing planning." Since the survey aimed to examine the importance of attributes in the destination choice context, regardless of the experience regarding 


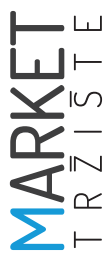

the destination, the "stated importance" measurement was applied, as suggested by Mikulić et al. (2016). The empirical data were collected using a structured questionnaire. A list of $8 \mathrm{di}-$ mensions and 27 attributes was defined, based on a review of relevant empirical studies (De Nisco et al., 2015; Blažević \& Peršić, 2012), and subsequently applied taking into consideration the specific traits of the destination. The research instrument covered 8 dimensions of destination attributes: environment (items 1-6), accommodation (items 7-8), cultural facilities (items 9-10), gastronomic offering (items 11-12), traffic in the destination (items 13-16), facilities in the destination (items 17-22), destination management (items 23-25), and local residents and destination safety (items 26-27). The questionnaire was created in Google Forms and used to conduct an online survey, through Facebook, from 26 May to 10 June 2018.

The first part of the questionnaire focused on perceived quality. Respondents were asked to evaluate the quality of each destination attribute' on a 5-point scale (1=insufficient to $5=$ excellent). The importance section formed the second part of the questionnaire, in which the respondents were asked to indicate on a 5-point scale ( $1=$ not important at all to $5=$ extremely important) the importance of each attribute for their tourist destination of choice. Additionally, they were asked to evaluate "the overall satisfaction with the destination" (1=insufficient to $5=$ excellent) in terms of perceived quality. The last part of the questionnaire was designed to capture the socio-demographic characteristics of the respondents (age, gender, education, personal monthly income, number of destination visits) and tourist loyalty to the destination. In this study, a 5-point scale was used following Norvell and Guy (1977), who considered that the use of a 4-point scale might produce distorted data if respondents were not familiar with its use, and Weijiters and others (2010), who recommended using a fully labelled 5-point scale for the general population, as cited in Chiung (2017).
The research population consisted of adult Croatian citizens. The survey was conducted on a convenience sample of domestic tourists who have visited the Opatija Riviera at least once. Domestic tourists were chosen for this study because of their importance in generating tourist demand in Opatija; namely, domestic tourists account for $16 \%$ of all arrivals and $11 \%$ of all overnight stays (Report of the Opatija Tourist Board, 2017), with a continuous growth trend in recent years. A total of 157 questionnaires were collected and included in the analysis. The sample size can be considered adequate and is above the recommended minimum level of at least five observations per variable (Hair, Black, Babin \& Anderson, 2014).

The internal consistency of the scales for each dimension was confirmed by Cronbach's alpha coefficient $(>0.70)$, as recommended by Hair and others (2014, p. 125). By designing a questionnaire based on existing knowledge and findings from previous studies, the validity of research results was ensured.

The second survey was conducted in relation to destination management to determine if there are differences between the quality of perceived and provided attributes and in overall satisfaction with the destination between tourists and destination management. The survey focusing on destination management was conducted at six tourist boards on the Opatija Riviera (Opatija, Kastav, Matulji, lčići, Lovran, and Mošćenička Draga) from 15 April to 16 June 2018. The data were collected through a personal survey based on a structured questionnaire that included the same dimensions and attributes as the tourist questionnaire. The tourist board managers evaluated the quality of provided attributes on a 5 -point scale ( $1=$ insufficient to $5=$ excellent). In terms of delivered quality, the managers were asked to assess "the overall satisfaction with the destination" (1=insufficient to $5=$ =xcellent). Information about gender and age was gathered for the socio-demographic profile of the tourist board managers. 
After both surveys were conducted, a preliminary data analysis was carried out using the SPSS 23 statistical software. The IPA, together with both descriptive (mean and standard deviation) and inferential (paired-sample t-test, independent sample t-test, bivariate correlation) statistics, were implemented in the data analysis.

\section{RESULTS AND DISCUSSION}

\subsection{Socio-demographic characteristics of respondents}

According to the gender structure of the sample, $78.3 \%$ of the respondents are female and $21.7 \%$ male. In terms of age, respondents aged 18-34 account for $56.7 \%$ of the sample, respondents aged 35-54 for 33.8\%, and those aged 55-74 for $9.5 \%$ of the sample. Regarding their educational level, $32.5 \%$ of the respondents reported they are high school graduates while $30.6 \%$ said they had a higher-education degree, and 36.9\% a university degree or a higher qualification. When asked about their personal monthly income, $40.1 \%$ of respondents reported having a monthly income of HRK 1,000-4,999, and 36.9\% a monthly income of HRK 5,000-9,999. An equal share of respondents (12.1\%) put their monthly income above HRK 10,000 and below HRK 1,000 respectively. The obtained results indicate a high degree of loyalty to the Opatija Riviera among domestic tourists, considering that 90\% of the respondents visited the Opatija Riviera more than four times, with $6 \%$ of them having visited the Opatija Riviera three times.

All the tourist board managers on the Opatija Riviera are female. In terms of their age, one manager is younger than 34, two are 35-44 years old, with three being between 45 and 54 years of age.

\subsection{IPA and attribute reliability analysis}

The reliability of research instruments and the attributes used was examined. Cronbach's alpha coefficients were applied to test the internal consistency of the attributes (Table 1).
TABLE 1: Attribute reliability

\begin{tabular}{|c|c|c|c|}
\hline \multirow{3}{*}{ No. } & \multirow{3}{*}{$\begin{array}{c}\text { Dimensions } \\
\text { of tourist } \\
\text { destination } \\
\text { offering }\end{array}$} & \multicolumn{2}{|c|}{ Cronbach's alpha } \\
\hline & & $\begin{array}{l}\text { Impor- } \\
\text { tance }\end{array}$ & $\begin{array}{l}\text { Perfor- } \\
\text { mance }\end{array}$ \\
\hline & & (I) & (P) \\
\hline 1 & Environment & 0.868 & 0.865 \\
\hline 2 & Accommodation & 0.756 & 0.868 \\
\hline 3 & Cultural facilities & 0.823 & 0.868 \\
\hline 4 & $\begin{array}{l}\text { Gastronomic } \\
\text { offering }\end{array}$ & 0.890 & 0.898 \\
\hline 5 & $\begin{array}{l}\text { Traffic in the } \\
\text { destination }\end{array}$ & 0.820 & 0.854 \\
\hline 6 & $\begin{array}{l}\text { Facilities in the } \\
\text { destination }\end{array}$ & 0.862 & 0.858 \\
\hline 7 & \begin{tabular}{|l|} 
Destination \\
management
\end{tabular} & 0.907 & 0.912 \\
\hline 8 & $\begin{array}{l}\text { Local residents } \\
\text { and destination } \\
\text { safety }\end{array}$ & 0.498 & 0.432 \\
\hline
\end{tabular}

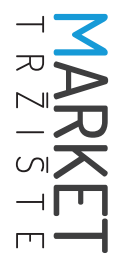

Table 1 shows eight dimensions of the tourist destination offering. Cronbach's alpha for the last dimension "local residents and destination safety" is lower than 0.7, which is recommended as the minimum level (Hair et al., 2014). For that reason, the inter-item correlation was performed. The intercorrelation stands at 0.353 for importance and 0.295 for performance. Given that Hair and others (2014) suggest that intercorrelations should exceed 0.30 , the authors decided to retain these factors so as to avoid losing useful information for destination managers.

Data on the importance and performance of destination attributes were used to calculate the gap by subtracting the average performance score from the average importance score of each attribute. The following paired-sample t-test was performed to determine the significance of the differences between the importance of destination attributes for selecting tourist destinations and the perceived quality of each attribute. The results presented in Table 2 indicate significant differences $(p<0.05)$ between the importance and the perceived quality of all analyzed destination attributes. 
TABLE 2: Importance-performance scores

\begin{tabular}{|c|c|c|c|c|c|c|c|c|}
\hline \multirow[t]{3}{*}{ No. } & \multirow[t]{3}{*}{ Dimensions/Attributes } & \multirow{2}{*}{\multicolumn{2}{|c|}{\begin{tabular}{|c} 
Importance \\
(I)
\end{tabular}}} & \multirow{2}{*}{\multicolumn{2}{|c|}{\begin{tabular}{|c|} 
Performance \\
(P) \\
\end{tabular}}} & \multirow{3}{*}{$\begin{array}{c}\begin{array}{c}\text { Gap } \\
\text { means }\end{array} \\
\text { (P-I) }\end{array}$} & \multirow{3}{*}{\begin{tabular}{|c|}
$\begin{array}{c}\text { Paired- } \\
\text { Sample } \\
\text { t-test }\end{array}$ \\
t value \\
\end{tabular}} & \multirow[t]{3}{*}{$\begin{array}{l}\text { Sig. } \\
\text { 2-tailed }\end{array}$} \\
\hline & & & & & & & & \\
\hline & & Mean & SD & Mean & SD & & & \\
\hline \multirow[t]{7}{*}{1} & Environment & 4.57 & 0.62 & 3.96 & 0.91 & -0.61 & & \\
\hline & Preserved environment & 4.45 & 0.73 & 3.82 & 0.97 & -0.63 & 7.730 & 0.000 \\
\hline & Clean sea & 4.78 & 0.53 & 3.59 & 0.96 & -1.19 & 14.962 & 0.000 \\
\hline & Cleanliness of beaches & 4.77 & 0.53 & 3.57 & 0.99 & -1.20 & 14.253 & 0.000 \\
\hline & Cleanliness of public places and streets & 4.48 & 0.62 & 3.77 & 0.95 & -0.71 & 8.560 & 0.000 \\
\hline & The beauty of landscapes & 4.58 & 0.62 & 4.45 & 0.74 & -0.13 & 2.132 & 0.035 \\
\hline & Destination climate & 4.34 & 0.70 & 4.19 & 0.84 & -0.15 & 2.079 & 0.039 \\
\hline \multirow[t]{3}{*}{2} & Accommodation & 4.47 & 0.73 & 4.09 & 0.76 & -0.38 & & \\
\hline & Comfort of accommodation & 4.39 & 0.75 & 4.11 & 0.72 & -0.28 & 3.794 & 0.000 \\
\hline & Cleanliness of accommodation & 4.54 & 0.70 & 4.06 & 0.75 & -0.48 & 6.393 & 0.000 \\
\hline \multirow[t]{3}{*}{3} & Cultural facilities & 4.13 & 0.80 & 3.81 & 0.93 & -0.32 & & \\
\hline & Cultural heritage and events & 411 & & 3.75 & & -0.39 & 4.373 & 0.000 \\
\hline & $\begin{array}{l}\text { Maintenance and preservation of } \\
\text { historical and cultural heritage }\end{array}$ & 4.12 & 0.83 & 3.87 & 0.94 & -0.25 & 2.726 & 0.007 \\
\hline \multirow[t]{3}{*}{4} & Gastronomic offering & 4.11 & 0.79 & 3.69 & 0.92 & -0.42 & & \\
\hline & Restaurant quality and diversity & & & & & -0.34 & 3.702 & 0.000 \\
\hline & Typical food and restaurants & 4.08 & 0.81 & 3.58 & 0.93 & -0.50 & 5.694 & 0.000 \\
\hline \multirow[t]{5}{*}{5} & Traffic in the destination & 4.12 & 0.89 & 2.98 & 1.08 & -1.14 & & \\
\hline & Quality of public transport service & 3.83 & 1.02 & 2.89 & 1.10 & -0.94 & 7.603 & 0.000 \\
\hline & Availability of local transport service & 3.89 & 0.99 & 3.04 & 1.12 & -0.85 & 7.103 & 0.000 \\
\hline & Easy inter-destination movement & 4.33 & & & 1.02 & -0.67 & 7.249 & 0.000 \\
\hline & Parking availability & 4.43 & 0.81 & 2.32 & 1.10 & -2.11 & 18.888 & 0.000 \\
\hline \multirow[t]{7}{*}{6} & Facilities in the destination & 3.80 & 1.01 & 2.94 & 1.06 & -0.86 & & \\
\hline & Sports facilities & 3.43 & 1.08 & 2.85 & 1.00 & -0.58 & 5.458 & 0.000 \\
\hline & $\begin{array}{l}\text { Entertainment opportunities (night } \\
\text { entertainment facilities) }\end{array}$ & 3.92 & 0.99 & 2.53 & 1.14 & -1.39 & 10.867 & 0.000 \\
\hline & Availability of guided tour services & 3.48 & 1.09 & 3.12 & 0.90 & -0.36 & 3.728 & 0.000 \\
\hline & Availability of health services and facilities & 4.12 & 0.91 & 3.31 & 1.11 & -0.81 & 6.709 & 0.000 \\
\hline & Shopping opportunities & 3.66 & 1.13 & 2.91 & 1.09 & -0.75 & 5.703 & 0.000 \\
\hline & $\begin{array}{l}\text { Availability of public services and facilities } \\
\text { (e.g. banks, etc.) }\end{array}$ & 4.20 & 0.84 & 2.94 & 1.12 & -1.26 & 10.846 & 0.000 \\
\hline \multirow[t]{4}{*}{7} & Destination management & 3.82 & 1.01 & 3.23 & 0.99 & -0.59 & & \\
\hline & Online promotion of the tourist destination & 3.83 & 1.03 & 3.27 & 0.98 & -0.56 & 5.293 & 0.000 \\
\hline & Quality of the tourist information center & 3.87 & 0.98 & 3.28 & 0.95 & -0.59 & 5.580 & 0.000 \\
\hline & $\begin{array}{l}\text { Social network activities of Opatija Riviera } \\
\text { tourist boards }\end{array}$ & 3.75 & 1.03 & 3.13 & 1.03 & -0.62 & 5.747 & 0.000 \\
\hline \multirow[t]{5}{*}{8} & Local residents and destination safety & 4.40 & 0.74 & 3.96 & 0.91 & -0.44 & & \\
\hline & Kindness of local residents & 4.20 & 0.88 & 3.59 & 1.07 & -0.61 & 6.552 & 0.000 \\
\hline & $\begin{array}{l}\text { Safety and security of the tourist } \\
\text { destination }\end{array}$ & 4.61 & 0.61 & 4.32 & 0.75 & -0.29 & 4.275 & 0.000 \\
\hline & Total quality & 4.17 & 0.83 & 3.47 & 0.97 & -0.70 & & \\
\hline & Overall satisfaction with the destination & 4.42 & 0.70 & 3.69 & 0.88 & -0.73 & 9.875 & 0.000 \\
\hline
\end{tabular}


The results show all gap scores to be negative, which means that the tourists' perceived quality of attributes is lower than their importance when selecting tourist destinations. Based on the average importance scores, it is evident that the majority of dimensions are highly important in destination selection, with a value above 4.00, except for "facilities in destination" (3.80) and "destination management" (3.82). On the other hand, all average scores regarding the perceived quality of attributes are below 4.00, except for "accommodation" (4.09). "Facilities in the destination" (2.94) and "traffic in the destination" (2.98) have the lowest average scores. From the calculated gap scores it can be concluded that the largest gap refers to "traffic in the destination" (-1.14), followed by "facilities in the destination" (-0.86). These results indicate significant and large differences between the 'importance of the attributes and their quality as perceived by tourists.

The results indicate that the perceived quality of the Opatija Riviera's destination attributes does not meet tourist expectations. Significant differ- ences $(p<0.05)$ between importance and perceived quality are found for all analyzed destination attributes. Based on the gap analysis results and significance calculations for destination attributes, the first hypothesis $(\mathrm{H} 1)$ is confirmed.

The importance-Performance matrix was created based on a calculation of average importance and performance scores for each destination attribute (Graph 1).

As can be seen from the IPA matrix, destination management should concentrate primarily on the improvement of "parking" (-2.11), "public services and facilities" (-1.26), "cleanliness of beaches" (-1.2), and "cleanliness of the sea" (-1.19), as attributes with the largest negative gap scores and, hence, the key weaknesses of the destination. The attributes with the lowest gap score are "the beauty of landscapes" (-0.13), "destination climate" (-0.15), "maintenance and preservation of cultural and historical heritage" (-0.25), "comfort of accommodation" (-0.28), and "safety and security" (-0.29), indicating that the destination should maintain the quality of these attributes as critical strengths of the destination.

\section{GRAPH 1: Importance-performance matrix}

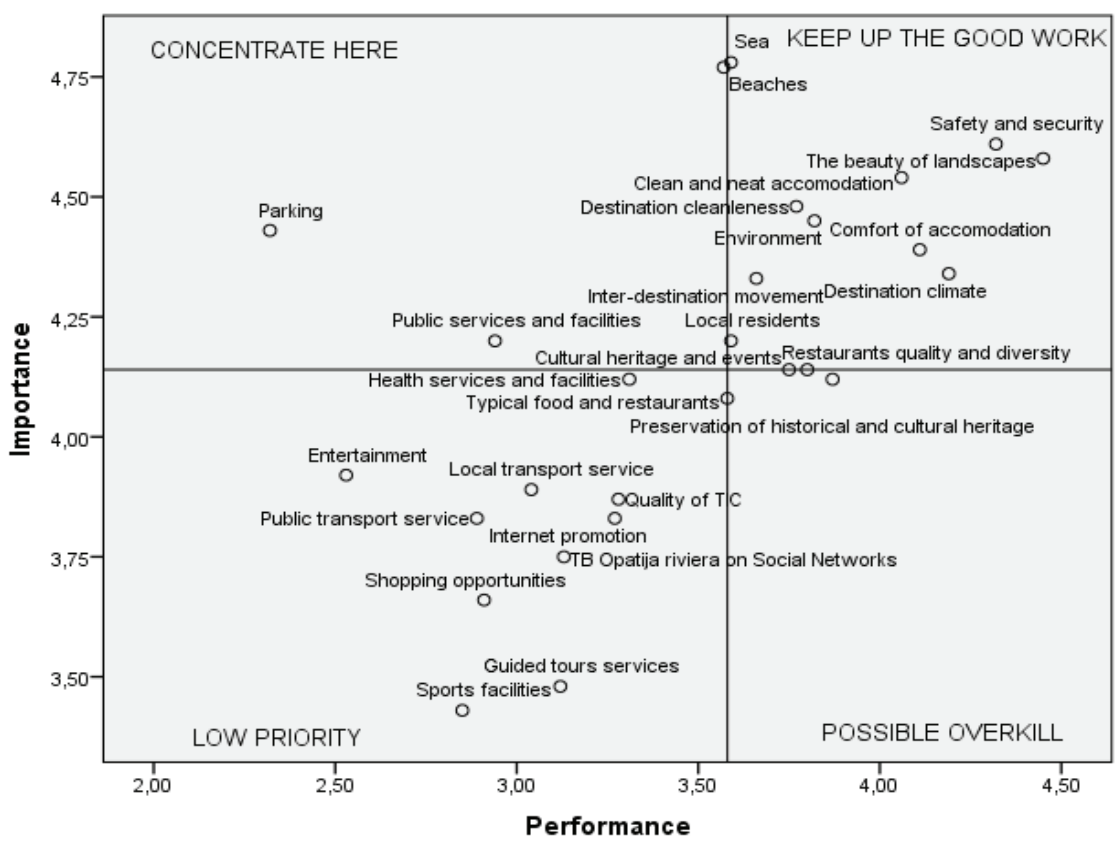




\subsection{Correlation analysis for quality and overall satisfaction}

Correlation analysis was carried out to assess the statistical relationship between the attributes' perceived quality and the level of overall satisfaction with the destination. For that purpose, the Pearson correlation coefficient was calculated for the total sample and for the three different age groups. The results are shown in Table 3.

TABLE 3: Correlation between destination attributes and overall tourist satisfaction - total sample and different age groups

\begin{tabular}{|c|c|c|c|c|c|}
\hline \multirow[b]{2}{*}{ No } & \multirow[b]{2}{*}{ Dimensions/Attributes } & Total & $\begin{array}{c}18-34 \\
\text { years old }\end{array}$ & $\begin{array}{c}35-54 \\
\text { years old }\end{array}$ & $\begin{array}{c}55-74 \\
\text { years old }\end{array}$ \\
\hline & & $\begin{array}{c}\text { Pearson } \\
\text { correlation } \\
\text { (r) }\end{array}$ & $\begin{array}{c}\text { Pearson } \\
\text { correlation } \\
\text { (r) }\end{array}$ & $\begin{array}{c}\text { Pearson } \\
\text { correlation } \\
\text { (r) }\end{array}$ & $\begin{array}{c}\text { Pearson } \\
\text { correlation } \\
\text { (r) }\end{array}$ \\
\hline \multirow[t]{7}{*}{1} & Environment & & & & \\
\hline & Preserved environment & $0.417^{* *}$ & $0.279 * *$ & $0.564^{* *}$ & $0.642^{* *}$ \\
\hline & Clean sea & $0.455^{* *}$ & $0.382^{* *}$ & $0.506^{* *}$ & $0.645^{* *}$ \\
\hline & Cleanliness of beaches & $0.522^{* *}$ & $0.445^{* *}$ & $0.604^{* *}$ & $0.554^{*}$ \\
\hline & Cleanliness of public places and streets & $0.425^{* *}$ & $0.316^{* *}$ & $0.531^{* *}$ & $0.531^{*}$ \\
\hline & The beauty of landscapes & $0.375^{* *}$ & $0.256^{* *}$ & $0.574^{* *}$ & 0.413 \\
\hline & Destination climate & $0.305^{* *}$ & $0.303^{* *}$ & 0.251 & $0.612^{*}$ \\
\hline \multirow[t]{3}{*}{2} & Accommodation & & & & \\
\hline & Comfort of accommodation & $0.507^{* *}$ & $0.398 * *$ & $0.661^{* *}$ & 0.443 \\
\hline & Cleanliness of accommodation & $0.525^{* *}$ & $0.362^{* *}$ & $0.763^{* *}$ & 0.443 \\
\hline \multirow[t]{3}{*}{3} & Cultural facilities & & & & \\
\hline & Cultural heritage and events & $0.513^{* *}$ & $0.560^{* *}$ & $0.566^{* *}$ & 0.255 \\
\hline & $\begin{array}{l}\text { Maintenance and preservation of } \\
\text { historical and cultural heritage }\end{array}$ & $0.508^{* *}$ & $0.457^{* *}$ & $0.606^{* *}$ & $0.700^{* *}$ \\
\hline \multirow[t]{3}{*}{4} & Gastronomic offering & & & & \\
\hline & Restaurant quality and diversity & $0.542^{* *}$ & $0.441^{* *}$ & $0.674^{* *}$ & 0.487 \\
\hline & Typical food and restaurants & $0.562^{* *}$ & $0.439 * *$ & $0.714^{* *}$ & 0.481 \\
\hline \multirow[t]{5}{*}{5} & Traffic in the destination & & & & \\
\hline & Quality of public transport service & $0.509 * *$ & $0.473^{* *}$ & $0.620 * *$ & 0.279 \\
\hline & Availability of local transport service & $0.582^{* *}$ & $0.576^{* *}$ & $0.653^{* *}$ & 0.182 \\
\hline & Easy inter-destination movement & $0.469^{* *}$ & $0.465^{* *}$ & $0.471^{* *}$ & 0.473 \\
\hline & Parking availability & $0.387^{* *}$ & $0.383^{* *}$ & $0.444^{* *}$ & -0.082 \\
\hline \multirow[t]{7}{*}{6} & Facilities in the destination & & & & \\
\hline & Sports facilities & $0.460^{* *}$ & $0.388^{* *}$ & $0.578^{* *}$ & 0.496 \\
\hline & $\begin{array}{l}\text { Entertainment opportunities } \\
\text { (night entertainment facilities) }\end{array}$ & $0.445^{* *}$ & $0.408^{* *}$ & $0.564^{* *}$ & -0.033 \\
\hline & Availability of guided tour services & $0.450^{* *}$ & $0.356^{* *}$ & $0.608^{* *}$ & -0.018 \\
\hline & Availability of health services and facilities & $0.456^{* *}$ & $0.418^{* *}$ & $0.479 * *$ & 0.491 \\
\hline & Shopping opportunities & $0.522^{* *}$ & $0.485^{* *}$ & $0.586^{* *}$ & 0.485 \\
\hline & $\begin{array}{l}\text { Availability of public services and facilities } \\
\text { (e.g. banks, etc.) }\end{array}$ & $0.561^{* *}$ & $0.567^{* *}$ & $0.578^{* *}$ & 0.331 \\
\hline
\end{tabular}




\begin{tabular}{|c|c|c|c|c|c|}
\hline \multirow[b]{2}{*}{ No } & \multirow[b]{2}{*}{ Dimensions/Attributes } & Total & $\begin{array}{c}18-34 \\
\text { years old }\end{array}$ & $\begin{array}{c}35-54 \\
\text { years old }\end{array}$ & $\begin{array}{c}55-74 \\
\text { years old }\end{array}$ \\
\hline & & $\begin{array}{c}\text { Pearson } \\
\text { correlation } \\
(\mathrm{r})\end{array}$ & $\begin{array}{c}\text { Pearson } \\
\text { correlation } \\
(\mathbf{r})\end{array}$ & $\begin{array}{c}\text { Pearson } \\
\text { correlation } \\
(\mathbf{r})\end{array}$ & $\begin{array}{c}\text { Pearson } \\
\text { correlation } \\
(\mathbf{r})\end{array}$ \\
\hline \multirow[t]{4}{*}{7} & Destination management & & & & \\
\hline & $\begin{array}{l}\text { Online promotion of the tourist } \\
\text { destination }\end{array}$ & $0.637^{* *}$ & $0.639 * *$ & $0.679^{* *}$ & 0.360 \\
\hline & Quality of the tourist information center & $0.600^{* *}$ & $0.627^{* *}$ & $0.581^{* *}$ & 0.385 \\
\hline & $\begin{array}{l}\text { Social network activities of Opatija Riviera } \\
\text { tourist boards }\end{array}$ & $0.651^{* *}$ & $0.663^{* *}$ & $0.680^{* *}$ & 0.367 \\
\hline \multirow[t]{4}{*}{8} & $\begin{array}{l}\text { Local residents and destination } \\
\text { safety }\end{array}$ & & & & \\
\hline & Kindness of local residents & $0.598^{* *}$ & $0.469 * *$ & $0.725^{* *}$ & $0.591^{*}$ \\
\hline & $\begin{array}{l}\text { Safety and security of the tourist } \\
\text { destination }\end{array}$ & $0.363^{* *}$ & $0.285^{* *}$ & $0.486^{* *}$ & $0.598^{*}$ \\
\hline & Overall satisfaction with the destination & 3.69 & 3.80 & 3.56 & 3.47 \\
\hline
\end{tabular}

${ }^{* *}$ Correlation is significant at the 0.01 level (2-tailed); ${ }^{*}$ Correlation is significant at the 0.05 level (2-tailed)

Descriptors of various sized correlation coefficients are clarified according to De Vaus (2004, p. 272). The results show that, in the total sample, correlation coefficients for all attributes are positive and significant at the 0.01 level (2-tailed). They can be classified as moderate (from 0.305) and substantial (up to 0.651), thus confirming the second hypothesis ( $\mathrm{H} 2)$. These findings are consistent with those of previous studies according to which the success of a destination depends heavily on a clear understanding of tourist satisfaction, which leads to destination loyalty (Gnanapala, 2015).

The results of different age groups show that, for the 18-34 and 35-54 age groups, correlation coefficients for all attributes are significant at the 0.01 level (2-tailed). There are positive and substantial correlations (between 0.581 and 0.679) of all attributes within the "destination management" dimension in the total sample, as well as in the $18-34$ and $35-54$ age groups ( $p=0.01)$. For tourists aged $18-34$, the overall satisfaction with the destination is also substantially correlated with the "availability of local transport service" $(r=0.576, p=0.01)$, "availability of public services and facilities" ( $r=0.567, p=0.01)$, and "cultural her- itage and events" $(r=0.560, p=0.01)$. A low level of correlation (between 0.2 and 0.3 ) is observed for the following attributes: "the beauty of landscapes", "preserved environment", and "safety and security." All the remaining attributes have a moderate correlation (between 0.3 and 0.49).

When compared with the total sample and other tourist age groups, the 35-54 age group has the highest values of the correlation coefficient for all attributes $(p=0.01)$. Attributes that are very strongly correlated with overall destination satisfaction are "cleanliness of accommodation" $(r=0.763, p=0.01)$, "kindness of local residents" $(r=0.725, p=0.01)$, and "typical food and restaurants" ( $r=0.714, p=0.01$ ). The majority of other attributes substantially correlate with overall satisfaction with the destination (between 0.5 and 0.69). The only attribute with a low correlation is "destination climate" $(r=0.251, p=0.01)$.

The last age group consists of tourists aged 55-74. Most of the evaluated attributes are not significantly correlated with the overall satisfaction with the tourist destination, and there are negative correlations for certain attributes. Only one attribute is very strongly correlated with 
total satisfaction, namely "maintenance and preservation of historical and cultural heritage" $(r=0.700, p=0.01)$. Substantial correlation is found for "clean sea" ( $r=0.645, p=0.01)$ and "preserved environment" ( $r=0.642, p=0.01)$. At the 0.05 level (2-tailed), the attributes "destination climate" $(r=0.612)$, "safety and security of the tourist destination" ( $r=0.598)$, "kindness of local residents" $(r=0.591)$, and "cleanliness of public places and streets" ( $r=0.531)$ are substantially correlated with the overall satisfaction. All the remaining attributes are not significantly correlated with total satisfaction for this age group.

When comparing the correlation results between different age groups, significant differences arise in the correlation of the overall satisfaction with destination attributes. These results are in accordance with the previous research results of Singh and Tiwari (2016), who found statistically significant differences between age groups regarding satisfaction with natural attributes, infrastructure, and services on site. For the 18-34 and 35-54 age groups, the research results indicate significant correlation coefficients at $p=0.01$ for all destination attributes. There are positive and substantial correlations (between 0.581 and 0.679) for attributes within the "destination management" dimension in both groups. The 35-54 age group, in comparison to the total sample and other tourist age groups, has the highest values of the correlation coefficient for all attributes at $p=0.01$. As for the 55-74 age group, most of the evaluated attributes are not significantly correlated with the overall satisfaction. Negative correlations for certain attributes have also been observed. Based on these results, the third hypothesis $(\mathrm{H} 3)$ is confirmed.

Additionally, an independent sample t-test was performed to determine if there is a significant difference between the perceived and provided quality of destination attributes. While the perceived quality included the tourists' perspective, the provided quality was observed from a destination management perspective. The results are presented in Table 4.

TABLE 4: Independent sample t-test (perceived and provided quality of the destination attributes)

\begin{tabular}{|c|c|c|c|c|c|c|}
\hline No. & Target group & $\mathbf{N}$ & Mean & $\begin{array}{c}\text { St. } \\
\text { Deviation }\end{array}$ & $\begin{array}{c}\text { Std. Error } \\
\text { Mean }\end{array}$ & \\
\hline 1 & Tourists & 157 & 3.57 & 0.61886 & 0.04939 & \\
\hline \multirow[t]{3}{*}{2} & Destination management & 6 & 3.72 & 0.58558 & 0.23906 & \\
\hline & & \multicolumn{2}{|c|}{$\begin{array}{l}\text { Leven's test } \\
\text { for equality of } \\
\text { variances }\end{array}$} & \multicolumn{3}{|c|}{ t-test for equality of means } \\
\hline & & $\mathbf{F}$ & Sig. & $\mathbf{t}$ & df & Sig. (2-tailed) \\
\hline \multicolumn{2}{|c|}{ Equal variances assumed } & .213 & .645 & -.595 & 161 & .553 \\
\hline \multicolumn{2}{|c|}{ Equal variances not assumed } & & & -.626 & 5.436 & .557 \\
\hline
\end{tabular}

$\mathrm{p}<0.05$

The above results and the significance value from Leven's Test $(p<0.05)$ indicate that there are no significant differences ( $p=0.553$ ) between the tourists' perceived quality and the provided quality of destination attributes from the destination management perspective. Thus, the fourth hypothesis $(\mathrm{H} 4)$ is rejected because the indepen- dent sample t-test implemented indicated no significant difference between the perceived and the provided quality of destination attributes. These results are contrary to the findings of Vodeb and Nemec Rudež (2017), who identified gaps between the market supply-side and demand-side perception of destination attributes. 


\section{CONCLUSION}

This study determined the significance of the gaps between the importance and the performance of destination attributes, measured from the tourists' perspective. It identified critical destination attributes and their relationships with the overall satisfaction in the total sample and in different age groups. Additionally, it examined the consistency between the perceived and the provided quality of destination attributes.

This research contributes to the body of knowledge by providing insights into the need for destination management to adjust destination attribute performance to the expectations of tourists on the target market, whose demands it should meet. This adjustment should be done by considering the differences between different groups on the target markets and the effect that destination attributes have on overall tourist satisfaction. Based on the research results, explicit recommendations for destination management are presented.

The results indicate that the perceived quality of the destination attributes of the Opatija Riviera does not meet tourist expectations, with significant differences found for all analyzed destination attributes. Destination managers should take this into consideration and focus on the destination attributes with the largest gap, which can be seen in the "Concentrate here" quadrant in the IPA matrix. Improvements in parking, public services and facilities, and cleanliness of the sea and beaches should be primary segments for addressing key weaknesses of the Opatija Riviera.

There are significant differences in the correlation of the overall satisfaction with destination attributes between different age groups. Positive and substantial correlations have been observed for the 18-34 and 35-54 age groups (between 0.581 and 0.679 ) regarding the attributes within the "destination management" dimension. In terms of destination offerings, "cultural heritage and events" have a substantial correlation in both age groups. The highest correla- tion in the 35-54 age group is found within the "gastronomic offering" dimension. For the 55-74 group, most of the evaluated attributes are not significantly correlated with overall satisfaction, and the highest level of correlation is found within the "environment" dimension. Based on these results, recommendations can be made to destination management. The significance and correlation value of destination attributes within different groups are valuable sources of information for destination management in targeting a specific market segment and creating services and tourism products adapted to these segments by incorporating special benefits for tourists and the promotional activities of DMOs on a target market. This information can help destination management minimize key destination weaknesses and create a marketing strategy for the target market according to the expectations of that market, as well as to emphasize attributes that are crucial for achieving tourist satisfaction.

The research presented in this paper has certain limitations. The first limitation is related to the case-based character of this study. Furthermore, it should be noted that the study measured the importance of attributes directly, using the "stated importance approach, so the results identify critical factors during the destination selection phase, rather than during the travel itself (Mikulić, 2019). Therefore, destination managers should understand that what is generally important for tourists when choosing a destination does not have to be important in driving their tourist experience. Since both approaches to importance measurement entail useful but different managerial implications, according to Mikulic and others (2016), the combination of stated and derived importance should be applied in future research. Azzopardi and Nash (2013) warn about the tendency of respondents to rate all attributes as highly important; however, the results of the IPA matrix show that the attributes are not concentrated in the upper part of the grid. Although this potential bias is reduced, it is still present and may be addressed using a different method combining these two

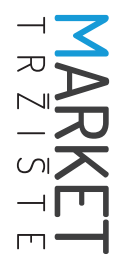


approaches. Thus, the specific findings cannot be generalized to the context of other destinations. In addition, there are drawbacks relating to the sample and the applied IPA. The demographic structure of the respondents is uneven, since most of them are female and younger in age, with only $9.5 \%$ of respondents aged 55-74.
That IPA has critics among researchers is well known. In explaining the implications for destination managers based on the results of the IPA analysis implemented, these results should be used as drivers for choosing tourist destinations, but not necessarily for creating tourist experience.

\section{References}

1. Abreu-Novais, M., Ruhanen, L., \& Arcodia, C. (2015). Destination competitiveness: what we know, what we know but shouldn't and what we don't know but should. Current Issues in Tourism, 19(6), 492-512.

2. Albayrak, T., Caber, M., González-Rodríguez, M., \& Aksu, A. (2018). Analysis of destination competitiveness by IPA and IPCA methods: The case of Costa Brava, Spain against Antalya, Turkey. Tourism Management Perspectives, 28, 53-61.

3. Alegre, J., \& Cladera, M. (2006). Repeat visitation in mature sun and sand holiday destinations. Journal of Travel Research, 44(3), 288-297.

4. Alegre, J., \& Cladera, M. (2009). Analysing the effect of satisfaction and previous visits on tourist intentions to return. European Journal of Marketing, 43(5/6), 670-685.

5. Alegre, J., \& Garau, J. (2010). Tourist satisfaction and dissatisfaction. Annals of Tourism Research, 37(1), 52-73.

6. Aziz, N., Ariffin, A. A. M., Omar, N. A., \& Siow, K. Y. (2011). An Investigation of International and Domestic Tourists' Satisfaction in Heritage Context: Implications for Destination Marketing. Jurnal Pengurusan (UKM Journal of Management), 33, 61-76.

7. Azzopardi, E., \& Nash, R. (2013). A critical evaluation of importance-performance analysis. Tourism Management, 35, 222-233.

8. Bagri, S. C., \& Kala, D. (2015). Tourists' satisfaction at Trijuginarayan, India: an importance-performance analysis. Advances in Hospitality and Tourism Research (AHTR), 3(2), 89-115.

9. Baker, D. A., \& Crompton, J. L. (2000). Quality, satisfaction and behavioral intentions. Annals of Tourism Research, 27(3), 785-804.

10. Beldona, S., \& Cobanoglu, C. (2007). Importance-performance analysis of guest technologies in the lodging industry. Cornell Hotel and Restaurant Administration Quarterly, 48(3), 299-312.

11. Bernini, C., \& Cagnone, S. (2012). Analysing tourist satisfaction at a mature and multi-product destination. Current Issues in Tourism, 17(1), 1-20.

12. Blažević, B., \& Peršić, M. (eds.). (2012). Tourism Destination Research. Opatija: Faculty of Tourism and Hospitality Management.

13. Boley, B. B., McGehee, N. G., \& Hammett, A. T. (2017). Importance-performance analysis (IPA) of sustainable tourism initiatives: The resident perspective. Tourism Management, 58, 66-77.

14. Chen, K. S., \& Chen, H. T. (2014). Applying Importance-Performance Analysis With Simple Regression Model and Priority Indices to Assess Hotels' Service Performance. Journal of Testing and Evaluation, 42(2), 455-466.

15. Chi, C. G. Q., \& Qu, H. (2008). Examining the structural relationships of destination image, tourist satisfaction and destination loyalty: An integrated approach. Tourism Management, 29(4), 624-636.

16. Chiung, S. Y. (2017). Evidence-based survey design: The use of midpoint on the Likert scale. Performance Improvement, 56, 15-23. 
17. Chu, R. K., \& Choi, T. (2000). An importance-performance analysis of hotel selection factors in the Hong Kong hotel industry: a comparison of business and leisure travellers. Tourism Management, 21(4), 363-377.

18. Ciunova-Shuleska, A., Palamidovska, N., \& Grishin, M. (2013). An empirical assessment of service quality in the context of travel agencies in the Republic of Macedonia. Market-Tržište, 25(1), 21-36.

19. Croes, R. (2011). Measuring and explaining competitiveness in the context of small island destinations. Journal of Travel Research, 50(4), 431-442.

20. Cronin Jr, J. J., \& Taylor, S. A. (1992). Measuring service quality: a reexamination and extension. Journal of Marketing, 56(3), 55-68.

21. Cvelbar, L. K., \& Dwyer, L. (2013). An importance-performance analysis of sustainability factors for long-term strategy planning in Slovenian hotels. Journal of Sustainable Tourism, 21(3), 487-504.

22. De Nisco, A., Riviezzo, A., \& Napolitano, M. R. (2015). An importance-performance analysis of tourist satisfaction at destination level: Evidence from Campania (Italy). European Journal of Tourism Research, 10, 64-75.

23. De Vaus, D. (2004). Analyzing Social Science Data - 50 Key Problems in data Analysis. London: Sage Publications.

24. Del Bosque, I. R., \& Martín, H. S. (2008). Tourist satisfaction a cognitive-affective model. Annals of Tourism Research, 35(2), 551-573.

25. Della Corte, V., Sciarelli, M., Cascella, C., \& Del Gaudio, G. (2015). Customer satisfaction in tourist destination: The case of tourism offer in the city of Naples. Journal of Investment and Management, 4(1), 39-50.

26. Devesa, M., Laguna, M., \& Palacios, A. (2010). The role of motivation in visitor satisfaction: Empirical evidence in rural tourism. Tourism Management, 31(4), 547-552.

27. Disastra, G. M., Hanifa, F. H., \& Sastika, W. (2018). Importance-Performance Analysis (IPA) on Tourists Satisfaction (Study in Ciamis Regency, Indonesia). Advanced Science Letters, 24(4), 2922-2925.

28. Djeri, L., Stamenković, P., Blešić, I., Milićević, S., \& Ivkov, M. (2018). An importance-performance analysis of destination competitiveness factors: case of Jablanica district in Serbia. Economic Research-Ekonomska istraživanja, 31(1), 811-826.

29. Dmitrović, T., Cvelbar, L. K., Kolar, T., Brencic, M. M., Ograjenšek, I., \& Žabkar, V. (2009). Conceptualizing tourist satisfaction at the destination level. International Journal of Culture, Tourism and Hospitality Research, 3(2), 116-126.

30. Do Valle, P. O., Silva, J. A., Mendes, J., \& Guerreiro, M. (2006). Tourist satisfaction and destination loyalty intention: A structural and categorical analysis. International Journal of Business Science \& Applied Management, 1(1), 25-44.

31. Duke, C. R., \& Mount, A. S. (1996). Rediscovering performance-importance analysis of products. Journal of Product \& Brand Management, 5(2), 43-54.

32. Dwyer, L., Dragićević, V., Armenski, T., Mihalič, T., \& Cvelbar, K. L. (2016). Achieving destination competitiveness: an importance-performance analysis of Serbia. Current Issues in Tourism, 19(13), 1309-1336.

33. Eusébio, C., \& Vieira, A. L. (2011). Destination attributes' evaluation, satisfaction and behavioural intentions: A structural modelling approach. International Journal of Tourism Research, 15(1), 66-80.

34. Fuchs, M., \& Weiermair, K. (2003). New perspectives of satisfaction research in tourism destinations. Tourism Review, 58(3), 6-14.

35. Ghanbri, A., Naghizadeh, R., \& Omrani, N. (2019). Tourists' satisfaction and loyalty to tourism product of Ardabil city: Emphasizing on demographic and social characteristics. Athens Journal of Tourism, 6(1), 39-56. 
36. Gnanapala, W. A. (2015). Tourists perception and satisfaction: Implications for destination management. American Journal of Marketing Research, 1(1), 7-19.

37. Griffin, T., \& Edwards, D. (2012). Importance-performance analysis as a diagnostic tool for urban destination managers. Anatolia, 23(1), 32-48.

38. Guadagnolo, F. (1985). The importance-performance analysis: An evaluation and marketing tool. Journal of Park and Recreation Administration, 3(2), 13-22.

39. Guzman-Parra, V. F., Vila-Oblitas, J. R., \& Maqueda-Lafuente, J. (2016). Exploring the effects of destination image attributes on tourist satisfaction and destination loyalty: an application in Málaga, Spain. Tourism \& Management Studies, 12(1), 67-73.

40. Hair, J. F., Black, W. C., Babin, B. J., \& Anderson, R. E. (2014). Multivariate Data Analysis. Boston, MA: Pearson Education Limited.

41. Homburg, C., \& Giering, A. (2001). Personal characteristics as moderators of the relationship between customer satisfaction and loyalty - An empirical analysis. Psychology \& Marketing, 18(1), 43-66.

42. Kim, J. J., Lee, Y., \& Han, H. (2019). Exploring competitive hotel selection attributes among guests: An importance-performance analysis. Journal of Travel \& Tourism Marketing, 36(9), 998-1011.

43. Kim, J., Suh, E., \& Hwang, H. (2003). A model for evaluating the effectiveness of CRM using the balanced scorecard. Journal of Interactive Marketing, 17(2), 5-19.

44. Kotler, P. (1999). Marketing management: The millennium edition (10 ${ }^{\text {th }}$ ed.). Upper Saddle River, NJ: Prentice Hall.

45. Kotler, P., Bowen, J. T., \& Makens, J. C. (2010). Marketing for Hospitality and Tourism (5 $5^{\text {th }}$ ed.). New Jersey, NJ: Pearson Education.

46. Kozak, M. (2003). Measuring tourist satisfaction with multiple destination attributes. Tourism Analysis, 7(3/4), 229-240.

47. Kozak, M., \& Rimmington, M. (2000). Tourist satisfaction with Mallorca, Spain, as an off-season holiday destination. Journal of Travel Research, 38(3), 260-269.

48. Kwanisai, G., \& Vengesayi, S. (2016). Destination attributes and overall destination satisfaction in Zimbabwe. Tourism Analysis, 21(1), 17-28.

49. Levenburg, N. M., \& Magal, S. R. (2004). Applying importance-performance analysis to evaluate e-business strategies among small firms. E-Service, 3(3), 29-48.

50. Li, J., Ali, F., \& Kim, W. G. (2017). Age matters: how demographics influence visitor perception and attitude at the destination level. International Journal of Innovation and Learning, 21(2), 149-164.

51. Manhas, P. S., \& Ramjit, J. (2011). Customer Perceptions Of Service Quality In Hospitality Industry: Importance Performance Analysis. Journal of Tourism Research, 2, 34-56.

52. Martilla, J. A., \& James, J. C. (1977). Importance-performance analysis. Journal of Marketing, 41(1), 77-99.

53. Meng, F., Tepanon, Y., \& Uysal, M. (2008). Measuring tourist satisfaction by attribute and motivation: The case of a nature-based resort. Journal of Vacation Marketing, 14(1), 41-56.

54. Mikulić, J., Krešić, D., Prebežac, D., Miličević, K., \& Šerić, M. (2016). Identifying Drivers of Destination Attractiveness in a Competitive Environment: A Comparison of Approaches. Journal of Destination Marketing \& Management, 5(2), 154-163.

55. Mikulić, J., \& Prebežac, D. (2011). Evaluating hotel animation programs at Mediterranean sun-andsea resorts: An impact-asymmetry analysis. Tourism Management, 32(3), 688-696.

56. Norvell, M., \& Guy, R. F. (1977). A comparison of self-concept in adopted and non-adopted adolescents. Adolescence, 12(47), 443-448.

57. Oliver R. L. (1997). Satisfaction: A behavioral perspective on the consumer. New York, NY: Irwin-McGraw-Hill. 
58. Oliver, R. L. (1980). A cognitive model of the antecedents and consequences of satisfaction decisions. Journal of Marketing Research, 17(4), 460-469.

59. Oliver, R. L. (1993). Cognitive, affective, and attribute bases of the satisfaction response. Journal of Consumer Research, 20(3), 418-430.

60. Pansiri, J. (2014). Tourist Motives and Destination Competitiveness: A Gap Analysis Perspective. International Journal of Hospitality \& Tourism Administration, 15(3), 217-247.

61. Parasuraman, A., Zeithaml, V. A., \& Berry, L. L. (1985). A conceptual model of service quality and its implications for future research. Journal of Marketing, 49(4), 41-50.

62. Pawaskar, P., \& Goel, M. (2017). Enhancing the effectiveness of marketing a tourist destination using satisfaction analysis. International Journal of Business and Systems Research, 11(1/2), 163-181.

63. Perović, Đ., Stanovčić, T., Morić, I., \& Peković, S. (2012). What socio-demographic characteristics do influence the level of tourist's satisfaction in Montenegro? Empirical analysis. Journal of Tourism, 14, 5-10.

64. Philip, G., \& Hazlett, S. A. (1997). The measurement of service quality: a new P-C-P attributes model. International Journal of Quality \& Reliability Management, 14(3), 260-286.

65. Pizam, A., \& Milman, A. (1993). Predicting satisfaction among first time visitors to a destination by using the expectancy disconfirmation theory. International Journal of Hospitality Management, 12(2), 197-209.

66. Pizam, A., Neumann, Y., \& Reichel, A. (1978). Dimentions of tourist satisfaction with a destination area. Annals of Tourism Research, 5(3), 314-322.

67. Porter, M. E. (2008). On competition. Brighton: Harvard Business Press.

68. Prebensen, N., Skallerud, K., \& Chen, J. S. (2010). Tourist motivation with sun and sand destinations: satisfaction and the wom-effect. Journal of Travel \& Tourism Marketing, 27(8), 858-873.

69. Pritchard, A., \& Morgan, N. (1998). 'Mood marketing' - The new destination branding strategy: A case study of 'Wales' The Brand. Journal of Vacation Marketing, 4(3), 215-229.

70. Queiroz Neto, A., Dimmock, K., Lohmann, G., \& Scott, N. (2019). Destination competitiveness: how does travel experience influence choice?. Current Issues in Tourism, 23(13), 1673-1687.

71. Ragavan, N. A., Subramonian, H., \& Sharif, S. P. (2014). Tourists' perceptions of destination travel attributes: An application to International tourists to Kuala Lumpur. Procedia-Social and Behavioral Sciences, 144(20), 403-411.

72. Rahim, A. G., Ignatius, I. U., \& Adeoti, O. E. (2012). Is customer satisfaction an indicator of customer loyalty?. Australian Journal of Business and Management Research, 2(7), 14-20.

73. Rajesh, R. (2013). Impact of tourist perceptions, destination image and tourist satisfaction on destination loyalty: a conceptual model. PASOS. Revista de Turismo y Patrimonio Cultural, 11(3), 67-78.

74. Rašovská, I., Kubickova, M., \& Ryglová, K. (2021). Importance-performance analysis approach to destination management. Tourism Economics, 27(4), 1-18.

75. Report of the Opatija Tourist Board, Opatija Tourist Board, 2017.

76. Shahrivar, R. B. (2012). Factors that influence tourist satisfaction. Journal of Travel and Tourism Research - Special Issue, 12(1), 61-79.

77. Singh, A., \& Tiwari, R. (2016). The role of destination attributes in promoting a tourist destination. Pacific Business Review International, 8(10), 9-20.

78. Singh, S. V., \& Tanwar, N. (2018). An Analysis of Tourist Satisfaction in Varanasi as Destination Perspective through Important Performance Analysis. Avahan: A Journal on Hospitality and Tourism, 5(1), 1-15.

79. Soldić Frleta, D. (2018). Shifts in tourists' attitudes towards the destination offering. Tourism and Hospitality Management, 24(2), 257-270. 
80. Sörensson, A., \& Von Friedrichs, Y. (2013). An importance-performance analysis of sustainable tourism: A comparison between international and national tourists. Journal of Destination Marketing \& Management, 2(1), 14-21.

81. Tontini, G., Picolo, J. D., \& Silveira, A. (2014). Which incremental innovations should we offer? Comparing importance-performance analysis with improvement-gaps analysis. Total Quality Management and Business Excellence, 25(7/8), 705-719.

82. Tribe, J., \& Snaith, T. (1998). From SERVQUAL to HOLSAT: holiday satisfaction in Varadero, Cuba. Tourism Management, 19(1), 25-34.

83. Vodeb, K., \& Nemec Rudež, H. (2017). Which attributes are important to tourists in a mature seaside destination? A case of Opatija in Croatia. Tourism: An International Interdisciplinary Journal, 65(3), 267-269.

84. Wang, T. L., Tran, P. T. K., \& Tran, V. T. (2017). Destination perceived quality, tourist satisfaction and word-of-mouth. Tourism Review, 72(4), 392-410.

85. Wang, X., Zhang, J., Gu, C., \& Zhen, F. (2009). Examining antecedents and consequences of tourist satisfaction: A structural modeling approach. Tsinghua Science and Technology, 14(3), 397-406.

86. Yoon, Y., \& Uysal, M. (2005). An examination of the effects of motivation and satisfaction on destination loyalty: a structural model. Tourism Management, 26(1), 45-56.

87. Yüksel, A., \& Yüksel, F. (2001). The expectancy-disconfirmation paradigm: a critique. Journal of Hospitality \& Tourism Research, 25(2), 107-131. 